POLITYKA ENERGETYCZNA - ENERGY POLICY JOURNAL

$2021 \uparrow$ Volume $24 \uparrow$ Issue $4 \uparrow 19-42$

DOI: $10.33223 / \mathrm{epj} / 143505$

Olena Shatilova $^{1}$, Tetiana SoboliEva ${ }^{2}$, Oleksandr Vostryakov ${ }^{3}$

\title{
Gender equality in the energy sector: analysis and empowerment
}

ABSTRACT: This article is devoted to topical issues of gender equality in the energy sector. It is a retrospective analysis of the problem of gender equality over the past 50 years in various countries and sectors of the economy. The situation with the improvement of the gender balance in general is changing, but unevenly, which increases the relevance of attention to the gender factor in policy development, particularly in the energy sector. It has been established that in the energy sector, there remain so-called "glass walls" and "glass ceilings" for the development of women's professional careers, which leads to horizontal and vertical segregation. The main barriers to gender balance in the energy sector are highlighted. The institutional conditions for ensuring gender equality in the energy sector have allowed for a more comprehensive view of the problem of gender occupational segregation. A number of institutional problems of gender equality in the energy sector are highlighted and characterized. These include: inconsistency of formal norms of gender equality and existing economic practices; lack of gender mainstreaming in energy policy making due to insufficient attention to social relations; the creation of additional tensions in industrial relations to ensure gender equality;

$\triangle$ Corresponding Author: Olena Shatilova; e-mail: olena.shatilova@gmail.com

1 Management, SHEE “Kyiv National Economic University named after Vadym Hetman”, Kyiv, Ukraine; ORCID iD: 0000-0003-3883-5567; e-mail: olena.shatilova@gmail.com

2 Management, SHEE “Kyiv National Economic University named after Vadym Hetman”, Kyiv, Ukraine; ORCID iD: 0000-0002-7818-145X; e-mail: tetiana.sobolieva@kneu.ua

3 Management, SHEE "Kyiv National Economic University named after Vadym Hetman”, Kyiv, Ukraine; ORCID iD: 0000-0002-9030-6569; e-mail: oleksandr.vostriakov@kneu.ua

2021. The Author(s). This is an open-access article distributed under the terms of the Creative Commons Attribution-ShareAlike International License (CC BY-SA 4.0, http://creativecommons.org/licenses/by-sa/4.0/), which permits use, distribution, and reproduction in any medium, provided that the Article is properly cited. 
unemployment of able-bodied women due to segregation in the labor market in the energy sector., Using a number of practical proposals for ensuring gender equality at the industrial and company levels, the authors propose a conceptual model of institutional support for gender equality in the energy sector. The implementation of these proposals would help eliminate gender imbalances in the energy sector and promote the development of energy companies on a sustainable basis.

KeYWORDS: gender gap, energy sector, gender balance, gender equality, institutional conditions

\section{Introduction}

The current situation in the world regarding climate change, environmental pollution and uneven economic development of countries in terms of poverty and access to resources requires the transition of the energy sector to new sources, and new technologies for their production and use within the social context of each country and region. Strengthening the role of women in the energy sector and increasing their involvement in various jobs in energy companies is important in addressing these issues.

The energy sector is undergoing one of the deepest transformations in 100 years due to technological and market failures (Dołęga 2019), but 13\% of the world's population still does not have access to modern electricity - mainly in Africa and South Asia. Without electricity, women and girls spend more hours extracting firewood and water; it is more difficult for hospitals to store vaccines in the refrigerator, for schoolchildren to do their homework at night, and for enterprises to be competitive (UN 2019). As the sector responds to the challenges of clean, reliable and affordable energy services, new ways are emerging to close the gender gap and strengthen performance throughout the energy value chain by involving women as potential workers, owners and consumers. Women are also another important segment of the electricity market because community members living around the tracks of energy projects can be powerful distribution agents to help reach even the most remote consumers and/or catalyze behavioral change to improve the acceptance of new energy technologies and products.

The development of local economies in the context of its integration into the European and world space is due to the need to improve the mechanisms and methods of interaction of all participants in economic relations (Dołega 2019). The growing interest in the energy sector requires the development of various forms and methods of management. The successful formation of a holistic institutional environment for the development of the energy sector will help attract investment and create conditions for the implementation of innovative activities. This requires a radical institutional transformation, which in turn will ensure the development of new progressive forms of innovation and the formation of new business models in the energy sector. In particular, special attention should be paid to improving the energy policy in the context of removing barriers to staff development and improving the efficiency of human resources in the energy sector. The relevance of this range of problematic issues led to the choice of the topic of this study. 


\section{The analysis of gender equality in the energy sector}

The processes of the development and improvement of the structure of the system of jobs in the energy sector in terms of the organizational, technical and socio-economic characteristics and the processes of equalization of the gender structure of employment are directly interrelated. The reduction of the "predominantly male" employment sector largely intersects with the reduction of "peripheral" employment - unattractive jobs for workers, which are traditionally problematic for candidates with regard to meeting the required qualifications. The scale of the labor shortage in the male occupations sector suggests that the costs needed to address the constraints and barriers to the realization of women's labor potential in the energy sector, particularly in the field of manual labor, are highly expected to mitigate the problem of chronic labor shortages for energy companies (USAID 2021). The elimination of organizational, technical and institutional constraints on women's access to employment and dynamic careers in the energy sector has significant potential to improve the staffing needs of energy companies.

However, in the modern world, gender inequality remains a phenomenon that typically occurs in various organizations, especially in the energy sector. Worldwide, the share of women in the labor force between 2019-2020 decreased by 3\% (from 51 to 48\%), women spend three times more time on unpaid childcare and other domestic work than men do. This percentage is likely to have increased during the COVID-19 pandemic due to school closures, the isolation of the elderly and an increase in the number of sick family members (WB 2020a). As a result, global wealth has decreased by $\$ 172$ trillion, and the wealth of human capital is underestimated by about one-fifth worldwide (Wodon et al. 2020).

European countries began to adopt legal acts on equal rights for women and men in the 1970s. The first act on this issue is the Law on Equal Rights for Women and Men, adopted in Sweden in 1972. The next countries to adopt similar legal acts were Norway (1978), Denmark (1978), France (2000) and Germany (2001). Since the 1970s, there has been significant progress in increasing legal gender equality, with women's rights now increasing to two-thirds of men's rights (WB 2020). An index measuring the legal support for the life cycle of women's from early on to retirement shows that there is a significant increase in the level of legal support for women in all groups of the world (Fig. 1). However, only eight countries (Sweden, Luxembourg, Latvia, Iceland, France, Denmark, Canada, and Belgium) have reached the maximum rating of 100 points.

However, of the 188 countries in the world with recorded data on equality in women's employment in industry (industrial positions), in only 62\% (117 countries) can women work in industrial roles in the same way as men. Moreover, seven of these countries have created equal conditions only in the last four years: Poland, Democratic Republic of Congo, and South Sudan (2017); Moldova and Niger (2018); Sao Tome and Principe (2019); Saudi Arabia (2020) (WB 2020b). The situation is changing, but unevenly, which increases the relevance of attention to the gender factor in policy development, particularly in the energy sector. The influence of the industry significantly determines the presence of women in the workforce, including in vario- 


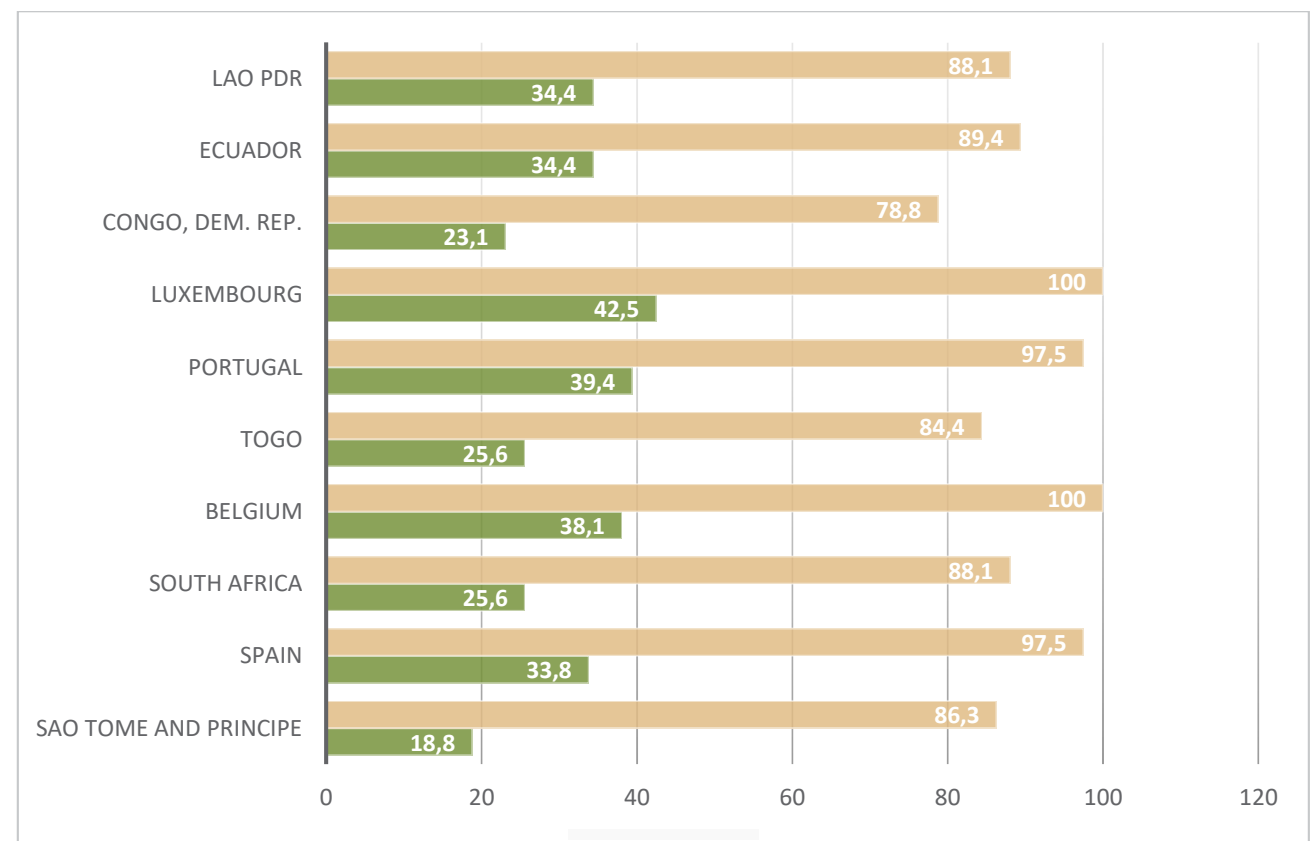

Fig. 1. Index of Legal Differences between Men and Women in 1970 and 2020

Source: formed by authors based on WB 2020b

Rys. 1. Wskaźnik różnic prawnych między mężczyznami i kobietami w latach 1970 i 2020

us positions in companies. Demonstrating different levels of the proportion of women in their stereotypicalpositions in corporate America (McKinsey and Company 2020), gender equality decreases markedly for women with increasing proportions of women fulfilling the role in question. In particular, this is noticeable in the energy sector, where at each level of the structure of companies' women less represented than in other industries (Fig. 2).

Since 2006, the World Economic Forum has defined the Global Gender Gap Index, which is based on four key dimensions: Economic Participation and Opportunity, Educational Attainment, Health and Survival, and Political Empowerment (WEF 2020). A consistent methodology is used for the calculation, which enables tracking of the dynamics in the reduction of this gap in the global dimension. The second largest gap after Political Empowerment is Economic Participation and Opportunity, which indicates the presence of a significant inequality in job opportunities and women's income levels compared to those of men. In 2020, the share of women in management positions in the private and public sectors increased by 2 to $36 \%$, but the situation in most countries requires improvement. Of concern is the deterioration of women's participation in the labor market. If $78 \%$ of adult men have a job in the market, the average for women is $55 \%$. The ratio of the strength of a woman compared with a man in a similar position is more than $40 \%$ lower; the income gap is over 50\%. It is important not only to reduce the gap in the Economic Participation and Opportunity sub-index, but also to significantly accelerate such 

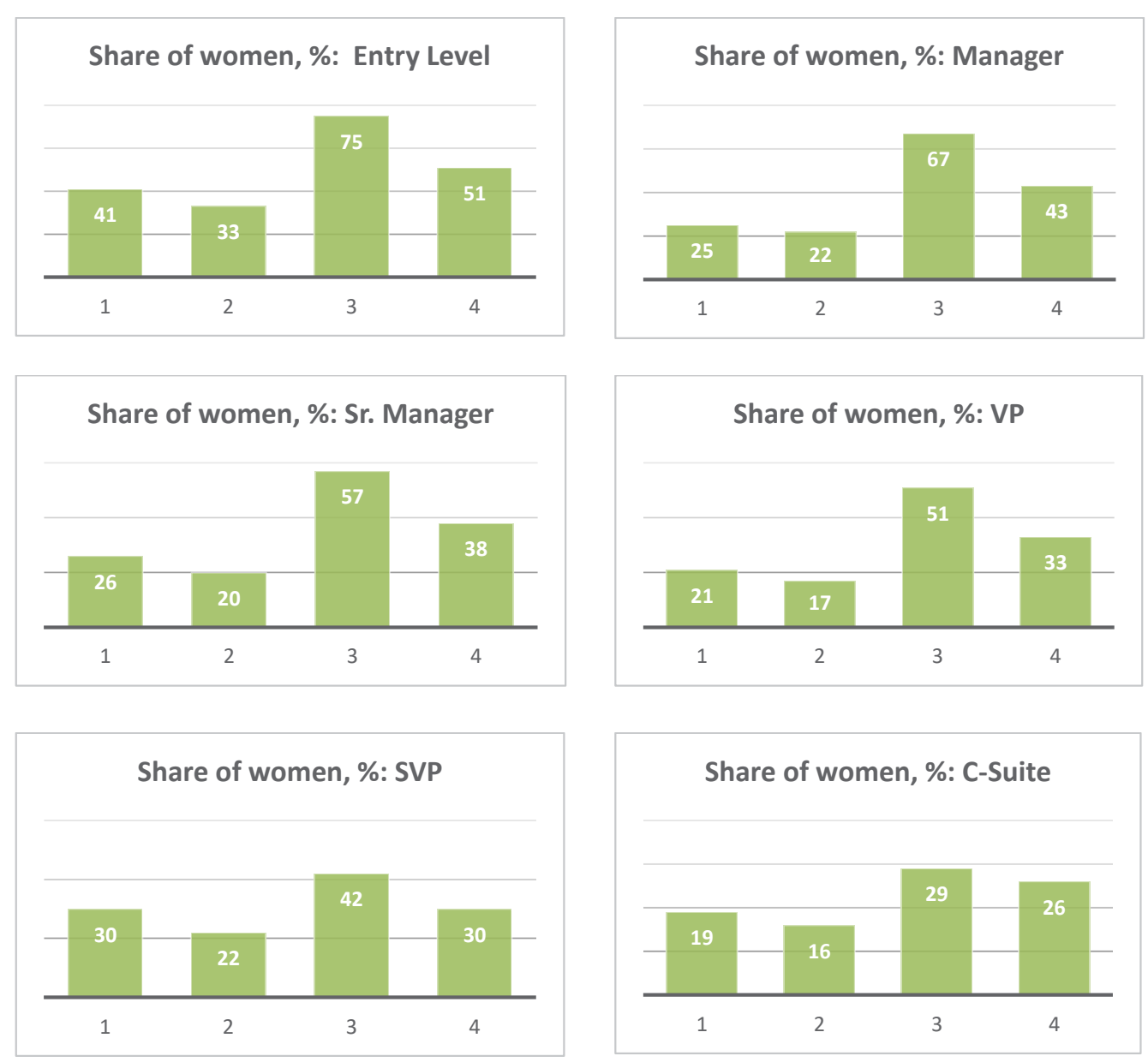

Fig. 2. The share of women at different levels of positions in corporate America [\%]

1 - energy, utilities, and basic materials, 2 - engineering and industrial manufacturing, 3 - healthcare systems and services, 4 - banking and consumer finance)

Source: formed by authors based on McKinsey and Company 2020

Rys. 2. Odsetek kobiet na różnych stanowiskach w korporacjach w Ameryce [\%]

a reduction because, according to calculations (WEF 2020), while maintaining the pace for the period 2006-2020, it will take 257 years to close this gap. Iceland has been the 2020 leader in reducing the gap (approximately $88 \%$ of all countries' gender gap) for many years in a row. The next positions in the ranking are occupied by Norway (84.2\%), Finland (83.2\%), and Sweden (82.0\%). Nicaragua (80.4\%), New Zealand (79.9\%), Ireland (79.8\%), Spain $(79.5 \%)$, Rwanda (79.1\%), and Germany (78.7\%) ranked fifth to tenth.

The Global Gender Gap Report 2021 explains the slowdown in the gap in the Economic Participation and Opportunity gap being due to the following trends: despite the growth of skilled 
professionals among women, there is a slight reduction in the gender pay gap; in addition, the share of women in management positions remains low; there is also a deterioration in progress towards a reduction in the gender gap due to the impact of the pandemic, which may in fact be $1-4 \%$ lower than reported in the 2021 report (WEF 2021).

The legislation ensures equal rights for women and men in their participation in political parties, education, business and professional development. It stipulates that the state must guarantee equal rights and opportunities to men and women in the energy sector Additionally, the normative and legal provision of observance of the principles and rules ensuring equal rights and opportunities for access to freely chosen and productive employment in the field of energy employment established by international obligations still focuses too little attention on specific restrictions and barriers to women's employment and the organizational features of labor processes in energy. This situation leads to a gap between formal norms and economic practices that correspond to each other only on formal grounds (the presence of norms), but not on the real resource provision of its implementation in the specific conditions of the industry and taking the specific needs of employees qualification characteristics into account.

One of the most discriminatory areas for women's rights is their professional activities in the energy sector. This phenomenon is primarily associated with personnel management policies in energy organizations which determines the hiring, training, promotion and dismissal of employees, as well as the terms of their remuneration. Moreover, institutional discrimination often leads to the appearance of sexism at different levels of social relations, including organizational levels. Taking into account the gender factor in the selection, hiring, training and dismissal of staff, as well as setting the standard for monetary remuneration, would significantly expand the representation of women in the energy sector.

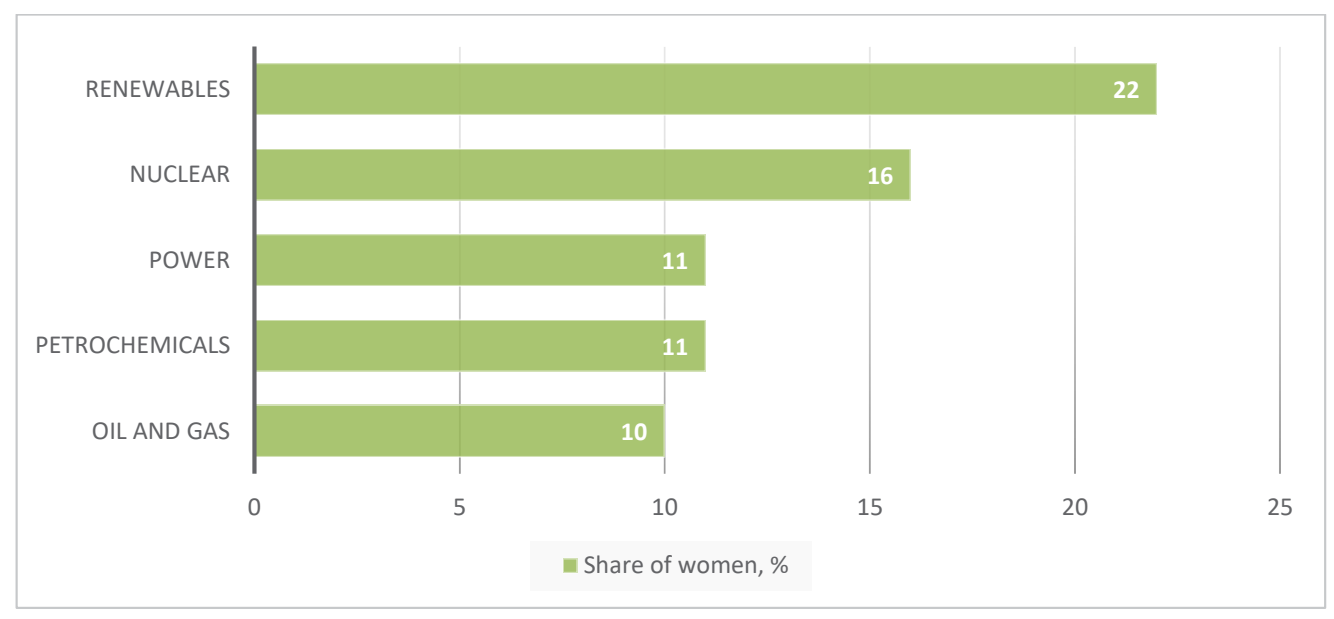

Fig. 3. Share of women in the energy workforce [\%]

Source: formed by authors based on GETI 2021

Rys. 3. Udział kobiet wśród osób pracujących w energetyce [\%] 
Data on the proportion of women in the energy sector differ according to the results of various studies, but all of them indicate their under-representation and thus a significant gender imbalance (GWNET 2019). According to the study (IRENA 2019), the share of women in the oil and gas industry is $22 \%$, and this figure is $32 \%$ in the renewable energy workforce. According to a different study (GETI 2021) which systematized the results of a survey of sixteen thousand energy professionals from 166 countries, women in the oil and gas industry are represented in the labor force by only $10 \%, 11 \%$ in petrochemicals and power, $16 \%$ in nuclear, and $22 \%$ in renewables (Fig. 3).

According to research, the most represented female segment in the workforce is observed in renewable energy. The IRENA 2019 study, noting an average of 32\% of employment of women in this segment, reports such a distribution between positions in companies $-28 \%$ of women are involved in STEM jobs (science, technology, engineering and mathematics), 35\% is the share of women in non-STEM technical jobs. Moreover, $45 \%$ were represented at the administrative level.

Among the main barriers to gender balance in energy are stereotypes of gender roles, norms of cultural and social behavior and the dominant hiring practice (IRENA 2019). The main barrier is the perception of gender roles. According to the results (IRENA 2019), 75\% of women are aware of such barriers, compared to only $40 \%$ of men. The perception of work in the energy sector as physically difficult has less and less reason considering the development of technology. The great potential for increasing the involvement of women is receiving education for STEM and technical jobs, which is a particularly promising area in renewable energy. Unequal opportunities are created at the beginning of a career, namely within education. Women are less educated on the subject of energy; moreover, women in developing countries have less awareness and access to information on vacancies as well as fewer networking opportunities.

When working in the energy sector and career advancement, women face barriers such as the glass ceiling because at least $75 \%$ of the board members in private companies are typically represented by men. Mobility requirements and a complex work schedule are additional barriers for women who care for children and other family members at the same time. Most companies do not have mentoring, flexible working hours, gender equity targets and training courses.

The presence of a glass ceiling explains the vertical segregation in the labor market in the energy sector. There is a level in the career hierarchy which a woman cannot rise above. Despite the fact that there are no formal barriers, women still do not have the opportunity to move above the "glass ceiling". Vertical segregation in the energy sector is accompanied by horizontal segregation. Women are often limited in their choice of occupations and activities that are promising in vertical career growth. The model of glass ceiling and glass walls describes the situation in which a woman is subjected to gender segregation when choosing a field of employment or vocational education. In our opinion, the reasons for this phenomenon are not only related to the demand but also to the supply of labor as some women can voluntarily accept traditional gender roles without any imposition. This, in turn, is a consequence of the dominance of outdated institutions of gender identity. Moreover, institutional discrimination often leads to the appearance of sexism at different levels of social relations, including organizational levels. A study of women's 
work in the Brazilian solar sector (GWNET 2019), for example, shows that $62 \%$ of women heard sexist comments when they were in an environment where men predominated.

Summing up the analysis, we can note the presence of positive dynamics in the field of equal rights and opportunities for women and men. At the same time, despite the declaration of equal rights and opportunities for women and men at the level of international organizations and individual countries, there is still a gender imbalance in the energy sector. Given that the main barrier to ensuring equal rights and opportunities for men and women in the energy sector is still the perception of gender roles, in our opinion, ensuring gender equality must be implemented comprehensively, including through its institutionalization.

\section{Institutional conditions for ensuring gender equality in the energy sector}

On the path to democratic development, each country seeks to build a civil society on a humanitarian basis. Most developed countries have made significant progress in recent years in studying and understanding gender issues. The development of society on a democratic basis in general and in companies in the energy sector in particular, requires a new content of legal norms as an important factor in regulating the relationship between the sexes in society. There is an urgent need today to adopt legal norms that would ensure the development of gender as equal and gender relations as equal, as the legal status of women at the level of society and family is an indicator of the development of the political, social and legal systems. However, today there are some contradictions related to the gaps in the regulation of gender equality in the energy sector, and the declaration of the institutional conditions of its development.

In modern conditions, a manifestation of the maturity of economic relations is the readiness of company management to take social aspects into account. This logic is determined by the whole course of social decisions and the dynamics of institutional processes taking place in the world today. In particular, the study of the effects of gender norms in institutions has contributed to the formation of a new trend in economic theory - feminist institutionalism (Lowndes 2010).

The twenty-first century is a period of egalitarian roles, where men and women are equal in their rights, a time of complete "equlibrium" for which opponents of gender inequality are fighting. The concept of "gender" is not a biological category, but comes from society and its culture. Thus born a person does not receive "gender" immediately, but acquires it in the process of inclusion in public life. Speaking of gender identity, it is worth mentioning such concepts as masculinity and femininity. In particular, masculinity is associated with courage, endurance, aggression, strength, power and success, and femininity is the complete opposite in terms of sensitivity, weakness, dependence and emotionality. These "correct" social notions of what it means to be a man or a woman have been formed for as long as we have been connected to society. Stereotypes, social roles and behavioral scenarios are what directly affect inequality - they 
create a certain hierarchy, stratification and power embedded in gender relations. Therefore, the goal of the modern world and society is to change the social reality and ensure gender equality in all spheres of people's lives.

As our analysis of employment in the energy sector has shown, there is gender occupational segregation, which originated in the distant past and continues to exist to this day. Furthermore, gender segregation is a manifestation of discrimination. Gender discrimination leads to "gender asymmetry", which divides men and women between different areas of employment. In summary, we can conclude that gender occupational segregation is an asymmetric distribution of workers by sex in different areas of employment: from sectoral to occupational and jobs.

There are external and internal constraints that negatively affect gender segregation in the energy sector. Internal constraints include gender stereotypes about modern women, these include: it is impossible to raise children and build a career at the same time; management positions are not for women, as they require a lot of effort to achieve them; a woman should not fight for a successful career because men do not choose women who are more assertive than they are. In conclusion, gender stereotypes encourage employers and workers to segregate, sometimes even subconsciously. Thus, gender segregation is formed and operates. External restrictions cause discrimination, which is an unequal opportunity in the labor market as defined by the International Labour Organization in Article 111 of the 1958 Convention concerning Discrimination in Respect of Employment and Occupation. The most common discriminations in energy companies include: pay for equal work, career building and training, employment and dismissal, and access to certain activities and positions. These factors directly affect the process of gender segregation in the energy sector.

Based on recent research, we have identified a number of institutional issues of gender equality in the energy sector (Fig. 4). These are: inconsistency of formal norms of gender equality and existing economic practices; lack of gender mainstreaming in energy policy making due to insufficient attention to social relations; tensions in industrial relations due to a formalized approach to ensuring gender equality; unemployment of able-bodied women due to the presence of segregation in the labor market in the energy sector.

On the one hand, in accordance with the requirements and recommendations of the United Nations and the Council of Europe, each European country is developing a legal framework for compliance with the principles and rules of ensuring equal rights and opportunities for free choice of profession. On the other hand, in the energy sector, there are specific restrictions and barriers to women's employment.

These obstacles are mainly due to the technological and organizational features of labor processes in the energy sector. As a result, a gap is formed between formal norms and existing economic practices. The existing legal norms are not always comparable with the real resource provision of their implementation, taking the specifics of the industry into account.

The traditional culture of most energy companies was formed at a time when the sphere of social relations was not a priority. In particular, the identification of gender issues is sometimes considered impractical, and the sphere of gender relations is considered unproblematic. As a result, strategies to ensure gender equality often remain overlooked and are not always considered 


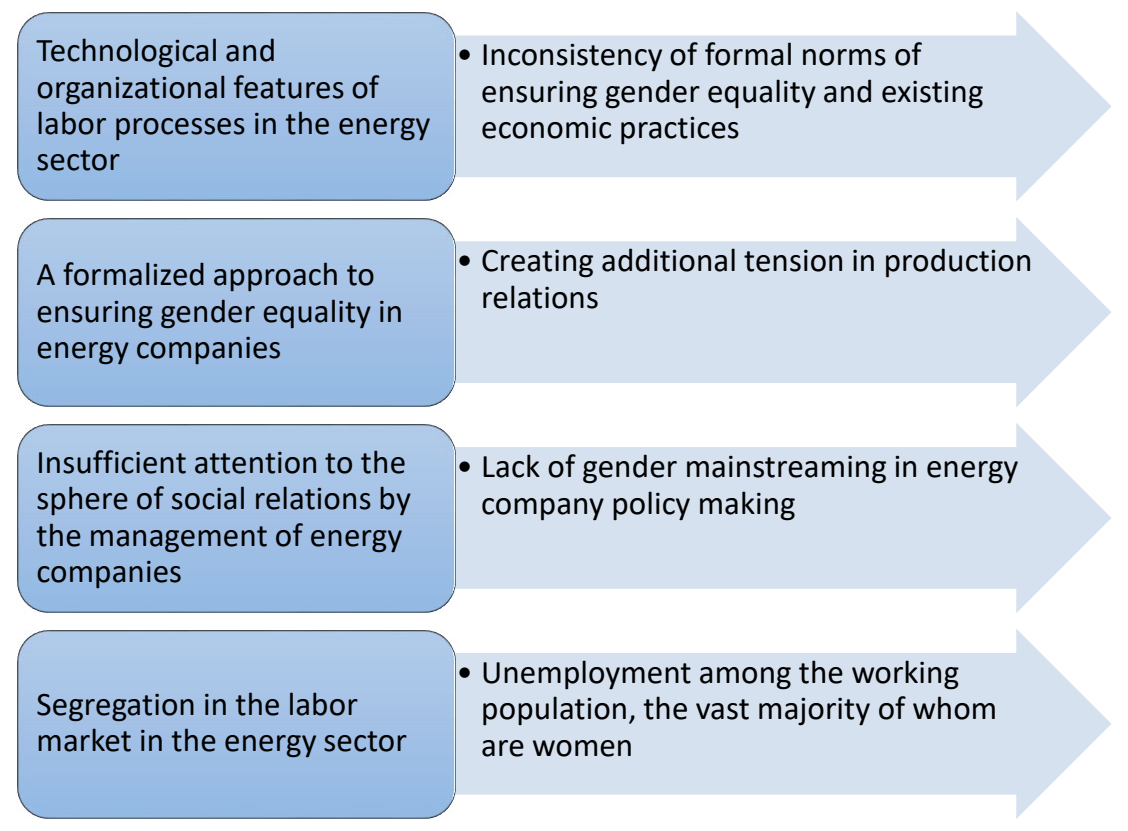

Fig. 4. Institutional problems of ensuring gender equality in the energy sector

Source: formed by authors based on USAID 2021

Rys. 4. Instytucjonalne problemy zapewnienia równości płci w energetyce

in shaping the domestic policies of energy companies. At the same time, the implementation of sustainable development goals must be accompanied by the transformation of the culture and policies of energy companies.

Ensuring gender equality in the energy sector is currently mostly implemented through the introduction of additional norms and regulations relating to employee behavior in the work environment. This situation creates an additional psychological burden on employees and is a source of tension in production relations, but it does not remove barriers to staff development and increases the efficiency of the company's human resources.

The management of energy companies does not pay enough attention to the sphere of social relations in general and issues of gender equality in particular. This situation is explained by the orientation of management to solve current problems on which the economic results of companies depend. The focus is on those issues that are easily fixed due to the dynamics of indicators and those which are not questioned by the company's stakeholders. In particular, these issues are the amount of income, the reduction of costs, the updating of material and technical base, the fulfilment of obligations to contractors, etc. Ensuring gender equality is one of the low priority issues. This is because, firstly, the problems of gender relations do not appear immediately, and secondly, the impact of gender relations on the performance of energy companies is indirect. 
One of the acute problems remains unemployment among the working population, the vast majority of which are women in general, in particular, segregation in the labor market in the energy sector. This situation is a consequence of the lack of vision in the management of energy companies and of a direct link between the problems of providing the company with skilled workers and the restrictions that prevent the full use of the potential of women's labor in the energy sector. Removing barriers to the employment of women in the predominantly male segment would not only promote human rights but also contribute to the resilience of energy companies to modern challenges and threats. At the same time, the problem of transformation of management of energy companies is inextricably linked with the problem of imperfection of legal support in the field of socio-economic relations. In particular, the economic and legal aspects of gender policy need to be improved.

The dynamics of career development provides access to corporate programs for the preservation and development of labor potential. This thesis has both theoretical (within the theory of human capital) and empirical justification in numerous works devoted to explaining the differences between the positions of women and men in the field of labor and employment (Blau and Kahn 2017). According to a study supported by the USAID Energy Security Project, the differentiation of the characteristics of women's and men's careers in the energy sector should be explained by taking into account the opportunities that women and men have to access programs to preserve and develop the labor potential of energy companies.

The authors of the report "Gender Aspects of Employment in the Energy Sector of Ukraine" highlight internal and external factors in the transformation of gender policy in the energy sector. Among the internal factors of the transformation of this attitude is the growing activity of women and men employed in energy who understand the importance of removing gender barriers and obstacles to the realization of human potential in energy and see gender equality as a way of improving the working lives of energy companies. By external factors, they mean the exacerbation of two groups of problems. Firstly, the problem of chronically "labor-deficient" specialties, for which there is a long period of filling "open vacancies". If among such vacancies a certain share is less accessible to women (for organizational, technical or other reasons), then the elimination of barriers to women's employment (in particular, through the elimination of harmful factors and the severity of labor processes) can significantly expand the number of applicants for vacancies and improve the staffing of energy companies. Secondly, the processes of integration of local energy into the European Energy Community, which require standardization of approaches to personnel management across European countries, where the attitude to gender equality, and the institutional, organizational and economic support for equal opportunities for women and men significantly differs from domestic business traditions (USAID 2021).

Given all the above, it can be concluded that ensuring a gender balance in the energy sector is impossible without the formation of appropriate institutional conditions. Improving gender policy in the energy sector is possible only in the current institutional environment of ensuring gender equality. Furthermore, the formation of the institutional environment for gender equality is a consequence of the emergence of state and non-state institutions that would take care of gender equality in the energy sector. Additionally, the emergence of institutions that would 
take care of gender equality is not possible without the transformation of formal and informal institutions of gender equality. Formal institutions of gender equality should first be enshrined in relevant laws and regulations at the levels of both state and industry, and should be enshrined in the internal regulations of energy companies. The crucial role of the transformation of informal institutions of gender equality should also be emphasized. In particular, the removal of one of the main barriers to equality in the energy sector is the stereotype that the energy sector is a field of male labor. Figure 5 shows a conceptual model of institutional support for gender equality in the energy sector.

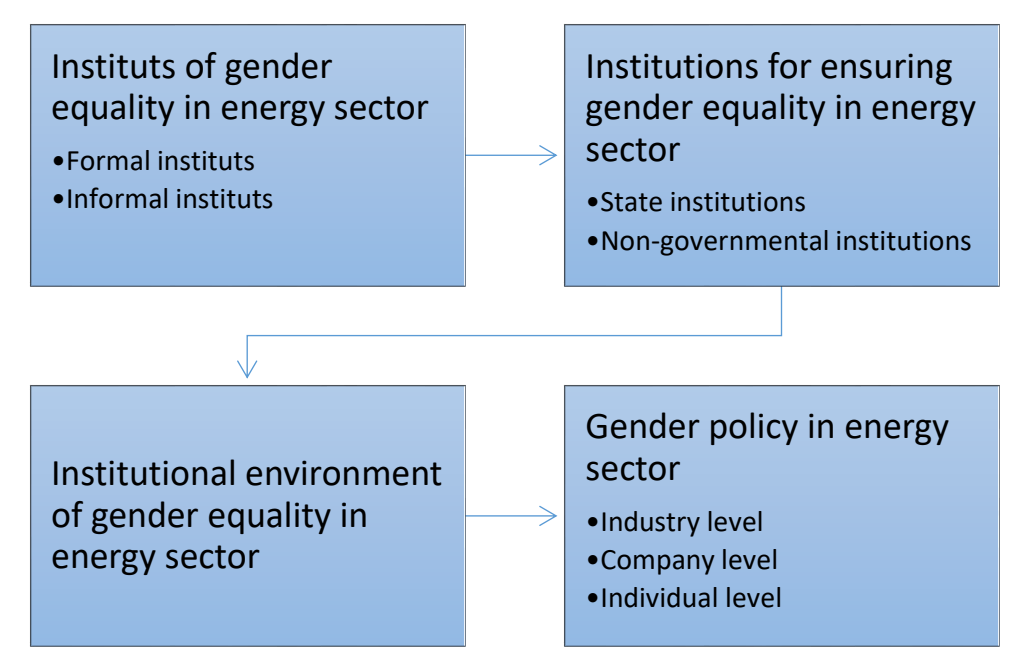

Fig. 5. Institution condition of gender equality in the energy sector

Source: authors' own work

Rys. 5. Instytucjonalny stan równości płci w energetyce

In conclusion, it should be noted that ensuring gender balance in the energy sector could only be achieved through the improvement of gender policy. Improving gender policy would contribute to the formation of effective management in the energy sector, which would have a positive impact on the resilience of national economies. Therefore, it is necessary to accelerate the process of development of social relations based on sustainable development (Gagnidze 2018; Ossowska and Janiszewska 2020), which contributes to the effectiveness of the economic growth of the state. 


\section{Areas of gender equality in the energy sector}

The energy sector is characterized by the phenomena of "glass ceiling" and "glass walls", which is caused by the influence of gender stereotypes about "male" and "female" professions and jobs. As a result, there remains significant gender asymmetry and segregation in the industry. When identifying ways to improve the gender balance in the energy sector, the focus should be on creating conditions to overcome certain barriers, the priority of which may vary from country to country, and between different companies of the energy sector. Moreover, if before the issues of gender equality at the macroeconomic level takes care of only by the country's authorities and international and public associations, then, in our opinion, another stakeholder - business should join in solving this problem. After all, the time of the establishment of beachy forced employers to accept this challenge and start promoting the topic of gender equality. Given the inconsistency of formal norms for ensuring gender equality with the existing economic practices, in our opinion, ensuring gender equality in the energy sector should be comprehensive. The postulates of gender equality declared at the macroeconomic level should be supported by their consistent implementation both at the industry level and at the level of individual energy companies.

At the sectoral level, improving gender policy is impossible without transforming the institutional environment to ensure gender equality in the energy sector. The formation of an appropriate institutional environment is impossible without the transformation of gender equality institutions themselves, as well as the emergence of state and non-state institutions that would ensure equal rights and opportunities for workers of both sexes in the energy sector. Based on this, in our opinion, one of the main prerequisites for eliminating gender segregation in the energy sector is the institutionalization of the concept of gender equality. The institutionalization of gender equality is a process of developing or transforming rules and procedures that influence a set of human interactions. The institutionalization of gender equality is a complex process of evolving rules and procedures that is dynamic by definition. As institutions must be considered as humanly devised contracts of social and political actors, the actual work of institutions is conducive to changes in society and its mode of governance. Figure 6 shows a conceptual model of the institutionalization of gender equality in the energy sector. Taking into account the gender factor in the selection, hiring, training and dismissal of staff, as well as setting the standard for monetary remuneration, would significantly expand the representation of women in the energy sector.

The proposed approach is implemented by a number of practical measures at each level: at the level of the energy sector, at the level of individual energy companies and at the level of individuals. The Figure 7 shows the practical examples of the proposed approaches. It should be noted that only the comprehensive implementation of the proposed measures in its synergy would ensure the achievement of the goals of sustainable development in the energy sector, such as ensuring gender equality. 


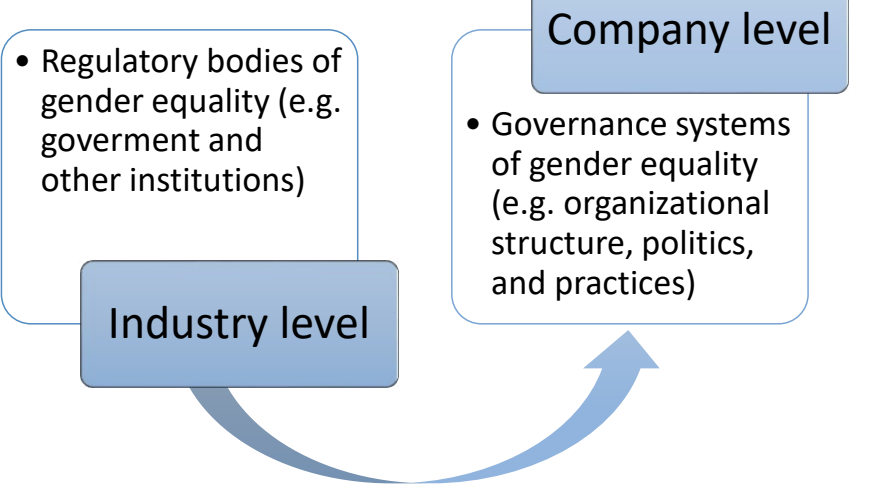

- Actors of gender equality (e.g. management styles, and working practices)

\section{Individual level}

Fig. 6. Institutionalization of gender equality in the energy sector

Source: authors own work

Rys. 6. Instytucjonalizacja równości płci w sektorze energetycznym

The implementation of the measures outlined in Figure 7 significantly contributes to improving the gender balance. For example, the implementation of "South African Government Programme Indicators: Women's Participation in the South African Utility-Scale Renewable Energy Independent Power Producer Procurement Programme" (South Africa) regulates the participation of women in executive bodies by tender documentation. "Quotas for Gender Parity", which were adopted in Rwanda in 2003, contributed to an increase in the proportion of women in government (49\% in 2003, 56\% in 2008, 64\% in 2013 and 61\% in 2018). Given that the share of women in the labor market in India is one of the lowest in the world (30\%), the government has passed a "Parental Policy" that requires equal pay for men and women and includes provisions for childcare in the workplace. "Creates First Legislative Gender Policy Instrument on the African Continent", passed by Kenya's Ministry of Energy, aims to raise awareness, change attitudes and maintain a culture of work in the energy sector. Part of the commitment and strategy is to strengthen the institutional framework for gender equality (GWNET 2019).

The Turkish company "Polat Energy" received a \$44-million loan under the commitment to increase the conditions of gender equality in the company. The "Gender Equality Loan" determines and improves credit conditions based on the assessment of gender equality indicators in the company. "Schneider Electric", which provides integrated and efficient power/energy management solutions combining energy, automation and software, has received many awards over the past two years for creating the conditions for gender equality. "Kiewit", an engineering and construction company in the large-scale renewable energy sector, implements a multipronged approach on gender and inclusivity - "KieWomen Equality Policy and Programme". "Siemens Gamesa" implements a diversity strategy that includes a variety of programs focused on inclusi- 


\section{Measures and practical examples at the industry level}

-Improving legislation in the context of standardizing equal rights and opportunities for women and men, including the application of a gender-oriented approach in the budget process

-Integrated gender mainstreaming in the activities of ministries, departments and other state executive bodies, including the creation of relevant units

- Promoting educational activities on gender equality and non-discrimination, in particular activities aimed at the harmonious combination of family and professional responsibilities and training on best practices that can be used to prevent discrimination

- Examples: "South African Government Programme Indicators: Women's Participation in the South African Utility-Scale Renewable Energy Independent Power Producer Procurement Programme" (South Africa), "Quotas for Gender Parity" (Rwanda), "Draft Bill to Encourage Participation of Women in STEM" (Brazil), "Parental Policy" (Brazil and India), "Creates First Legislative Gender Policy Instrument on the African Continent" (Kenya)

\section{Measures and practical examples at the company level}

- Carrying out gender and legal examination of the existing internal normative documents of the company and in case of absence to supplement them with norms on observance of the principles of non-discrimination

-When developing new or revising existing company statutes and employment contracts, provide for a separate section (paragraph) on compliance with the principles of equality and non-discrimination of employees

-Analysis of the company's statistical reporting, including financial and management, for the presence of disaggregated data, in particular by gender, age, level of education, length of service, position

-Examples: "Gender Equality Loan" (Polat Energy), "Attracting and Retaining Women" (Schneider Electric), "KieWomen Equality Policy and Programme" (Kiewit), "Flexible Work programmes and Transparent Pay-Gap Analysis" (Siemens Gamesa), "Employee-owned Solar Installation Company Values Employee-centred Equality" (Namaste B-Corporation), "Promoting Women Employee Professional Development to Create More Women Managers" (ITAIPU Binacional)

\section{Measures and practical examples at the individual level}

-Attending trainings to explain the basic principles of gender equality, discrimination, bullying, harassment, sexual harassment, and other forms of aggressive behavior in the workplace -Adherence to ethical behavior in the workplace, including avoiding insults, remarks and jokes that embarrass, and other verbal harassment, lustful looks and gestures associated with sexuality, as well as inappropriate comments about appearance, clothing, age, or marital status of their colleagues

-Examples: "Women in Engineering Program" (Australia), "We Saved You a Seat Pilot Project" (Canada), "Mentorship for Women in STEM: HunterWiSE" (Australia), Women in Construction (Brazil), "GWNET Mentoring Programmes"

Fig. 7. Measures and practical examples of gender equality in the energy sector institutionalization Source: formed by authors ground by GWNET 2019 
veness and gender equality, for example, "Flexible Work Programmes and Transparent Pay-Gap Analysis". In 2018, Namaste B-Corporation began implementing a paid in-house education project to raise the awareness of its staff on diversity and inclusiveness and equality. The world's largest hydroelectric power plant, ITAIPU Binacional (Brazil), implements a program to motivate female employees to professional development "Promoting Women Employee Professional Development to Create More Women Managers", which has led to an increase in the number of female managers from $10-21 \%$ in nine years (GWNET 2019).

The implementation such educational projects, as "Women in Engineering Program" (Australia), "We Saved You a Seat Pilot Project" (Canada), "Mentorship for Women in STEM: HunterWiSE" (Australia), Women in Construction (Brazil), "GWNET Mentoring Programmes" provide awareness of issues of diversity, equality and inclusiveness. At the individual level, they aim to inspire young women to pursue a career in engineering and there are initiatives aiming to increase the enrolment of women in STEM programs (GWNET 2019).

We propose to implement gender equality at the level of individual energy companies through the implementation of a four-step model (Fig. 8). Awareness of gender imbalances should be the first step towards ensuring gender equality in an energy company.

This stage should begin with the establishment of a working group which should include representatives of all interested internal stakeholders of the company. The working group should collect data on the quantitative ratio of male to female employees in the company, the level of their salaries, the quantitative ratio of both sexes in the company's management positions, the features of career advancement, etc. An important step at this stage is to critically review the company's current strategies and policies to take into account gender issues.

Improving the company's existing gender policy, developing a new version and introducing measures to ensure gender equality in energy companies can be carried out in different areas and at different levels of companies. Thus, at the highest level of companies, the focus should be on developing or revising gender policies to strengthen the place of women in the workforce, to broadcast and uphold the values of gender equality, and to ensure that any gender-based violence is unacceptable. To strengthen gender equality, women need to move more actively to higher levels of management in companies, which allows them to take a more active part in decision -making and management. The establishment of quotas for women's membership in the relevant bodies of companies will also contribute to this. The use of quotas in companies demonstrates to employees that attention is being paid to gender diversity and awareness of its importance, providing women with additional opportunities for employment and career advancement. On the other hand, some women perceive such a quota as a confirmation of the biased perception of men as more qualified and desirable workers, and therefore a woman can only get a job or position thanks to the quota. An important aspect of creating a culture of "gender equality" in companies is educational work through the organization of focus groups, seminars, workshops and discussions on the benefits of gender diversity. The strengthening of such a culture should be facilitated by a policy of "zero tolerance" for any sexual harassment in the workplace. This requires clear inclusion in the company's documentation concerning relevant provisions and regulations. Moreover, such norms will only work if they strictly adhered to, constantly 


\section{Awareness of the problem of gender inequality}

\begin{abstract}
Creation of a working group
from the company's internal stakeholders
\end{abstract}

Collection of data on the state of gender balance in the company
Review of the company's strategy and policy to take into account gender aspects

\section{Introduction of policies and procedures to ensure gender equality}

Development of strategy, policy and rules to ensure gender equality in the company
Integration of gender approaches into all operational processes of the company
Establishing a system of external and internal communications on the implementation of approaches and policies

\section{Launch partnerships with other organizations to promote gender equality}

Support for international and national initiatives to promote gender equality
Establishing partnerships with relevant governmental and non-governmental institutions concerned with gender equality

\section{Measuring the effectiveness of the implementation of measures to ensure gender}

equality

Collection of data on the results of the implementation of measures to ensure gender equality
Reporting on the results of the implementation of measures to ensure gender equality
Dissemination of information on the implementation of measures to ensure gender equality

Fig. 8. Model of implementation of gender equality in energy companies Source: formed by authors ground by UNFPA 2019

Rys. 8. Model wdrażania równości płci w przedsiębiorstwach energetycznych 
monitoring progress on these issues and responding to violations. The company's management should establish gender goals and monitor their implementation, including the participation of women in vocational training and professional development. Transparency and publicity of such information also contributes to the effectiveness of building a "gender balance" in companies. In particular, the results of the study (Bennedsen et al. 2019) show that the publicity of information of employees' salaries helps to reduce the income gap between men and women for equal work.

Another area (driver) of gender diversity is the support of flexible and family-friendly work schedules. It provides an opportunity to choose the optimal work schedule for a woman, taking into account the specifics of professional responsibilities, position, remoteness of the workplace and the need to combine work with caring for family members. Flexibility of work schedules provides such advantages as increases in labor productivity and a reduction of expenses for the selection of personnel. The effectiveness of alternative modelling is evidence by increased retention rates and reduced absenteeism (GWNET 2019).

An important area is the levelling of bias in recruitment and throughout the career path. At the recruitment stage, attention should paid to the correctness of the requirements and description of the position and responsibilities of the applicant, as well as to ensuring a fair process of selection of candidates for the position. Vacancy information should be public and understandable to all candidates, including career opportunities and salaries. The implementation of the hiring policy should monitored and its effectiveness should be analyzed with information of those responsible for the results.

The third step in implementing gender equality should be to establish partnerships with other organizations. In this way, support for international and national initiatives to ensure gender equality, such as participation in information and education campaigns, and the celebration of important dates, plays an important role. These measures are primarily aimed at forming and maintaining a positive image of the company. Broadcasting the values of gender equality helps to attract more and more women to work in the company. As a result, horizontal segregation in the labor market in the energy sector decreases. Establishing partnerships with educational organizations strengthens the competencies for the professional development of women in energy companies and, as a result, reduces vertical segregation in the labor market. The involvement of women and their training can take place through inclusive education, active participation in training programs, and special training programs for new professions and technologies in the energy sector. One of the important requirements for career advancement is the ability to obtain mentor support, including adaptation and mentor support after a break, so strengthening mentoring for women in energy companies is an important step in strengthening the gender balance.

Many international and national projects, initiatives, programs and networks are effective tools to increase women's involvement in the energy sector, these include: Women of Renewable Industries and Sustainable Energy, Hypatia in Germany, Women in Sustainability (WiS) India, the International Network on Gender and Sustainable Energy, Women in Renewable Energy (WiRE, Canada) and many others, where women can learn about career opportunities, skills and job requirements (GWNET 2019). 
The final stage of implementing gender equality in an energy company should be to measure the effectiveness of the implementation of the measures. The company should evaluate how employees have perceived policies and procedures by conducting a separate survey or including relevant issues in annual staff engagement surveys. The data collected during the study should be presented in the form of an annual report. An important step at this stage is the disclosure of the collected information, both inside the company and outside. Data collection, the comparison of results and measuring the effectiveness of the implemented measures to ensure gender equality is very important in the context of cultural transformation in energy companies, as well as changing the worldview of their leadership, drawing attention to social issues.

In conclusion, the challenges for improving the position of women in companies are serious and have been exacerbated by the Covid-19 pandemic (McKinsey and Company 2020). Many women today are faced with the choice to quit their jobs or change professions. Companies in this situation should take measures to ensure the stability of work, additional opportunities for development and optimization of personal work tasks. Changing work schedules increases the online workload by many hours, which requires the management of companies to determine the flexibility of work with the establishment of clear ranges of communication and interaction. The revision of performance criteria reduces psychological pressure and leads to improved productivity. The challenges of a pandemic reinforce prejudices against women's productivity and commitment, as they are forced to spend more time with family members. Participation in training about unconscious biasand increasing attention on organizational communication with regard to women's success and career advancement are useful tools for overcoming this bias. The extension of policies and programs allows women to take additional paid leave and attend medical examinations or consultations with a psychologist. Well-established communication about the situation and changes in the company and the constant provision of information and support to employees significantly improves their professional responsibilities.

\section{Conclusion}

In summary, the transformation of the energy sector towards sustainable development requires the revision and actualization of the role of women to ensure such a transition. Strengthening the integration of women into the energy sector through new technologies expands the possibilities of their inclusion at all stages of the value chains from household consumption to the creation of SMEs and work in various positions in energy sector corporations. Creating new business models in solar energy or energy supply utilities requires many new skills and professions, which increases women's chances of employment in renewable energy. Analysis of gender diversity in the energy sector shows a significant imbalance in the representation of women in the workforce relative to men, which not only reduces the creativity and profitability of businesses, but also 
worsens the economic and social situation due to gaps in gender opportunities. This situation is especially typical in traditional energy industries. The situation is better in the case of renewable energy, which is associated with the development of new technologies that provide more opportunities for women to be involved in this sector, as well as greater interest and commitment of women themselves to the principles of a green economy. The growing proportion of women in the energy sector faces both a number of cultural and social barriers at the societal level and imperfect gender policies in companies. Such barriers occur both at the beginning of women's careers due to less access to information on career opportunities and training in energy, and within the workforce in companies during their career development. While cultural and social barriers are largely driven by traditional perceptions of gender roles by both men and women, women in companies face challenges such as limited access to management positions, pay gaps, fewer or a lack of opportunities to improve skills and training, difficulties with reconciling work schedules with family care responsibilities. The revision of the policy regarding gender diversity in energy companies requires attention and the implementation of a number of measures aimed at creating equal conditions for women and men in terms of income, career opportunities and professional development, and the improvement of working conditions and infrastructure. It is important to form a culture of gender diversity in the company, which is implemented through training programs, official declaration and adherence of staff to gender values, and the implementation of gender goals in practice.

Promising directions of our further research in this area include a study of gender aspects at the level of individual energy companies in Ukraine. There is a positive trend of growing interest in ensuring equal rights and opportunities for women and men in Ukraine. This issue, in our opinion, is very relevant for the following reasons. Firstly, women make up the majority of the population of Ukraine (total permanent population of 22,528,292 women and 19,455,272) and the majority are in the age range which form the basis of the economically active population $(13,754,231$ men and 14,713,803 women aged 15-64) (SSSU 2020). Secondly, ensuring gender equality, as one of the goals of sustainable development, is an extremely important component in the process of Ukraine's integration into the European space. Our colleagues, with the support of the USAID Energy Security Project, have prepared a detailed report on gender aspects of employment in Ukraine's energy sector (USAID 2021). The study analyzed the features of gender balance of labor supply and demand, assessed the level of tension in the labor market, and examined the potential of human capital in the energy sector of Ukraine, in particular, the vertical occupational mobility of women and men. Based on the results of the study, a number of practical recommendations were formed for the Ministry of Energy of Ukraine and for the Ministry of Education and Science of Ukraine. Taking into account these developments, we plan to deepen the study of gender equality at the level of individual energy companies in Ukraine. Based on the analysis of statistical, financial and management reporting, and by conducting a series of opinion polls in leading energy companies in Ukraine, we are planning to identify compliance with equal rights and opportunities for women and men, and to develop a set of practical recommendations for their improvement. 


\section{References}

Bennedsen et al. 2019 - Bennedsen, M., Simintzi, E., Tsoutsoura, M. and Wolfenzon, D. 2019. Gender Pay Gap Shrinks when Companies are Required to Disclose Them. Harvard Business Review. January 23. [Online] https://hbr.org/2019/01/research-gender-pay-gaps-shrink-when-companies-arerequired-to-disclose-them [Accessed: 2021-08-15].

Blau, F.D. and Kahn, L.M. 2017. The Gender Wage Gap: Extent, Trends, and Explanations. Journal of Economic Literature 55(3), pp. 789-865.

Cirella et al. 2020 - Cirella, G., Goncharuk, A., lo Storto, C. and Russo, A. 2020. Exploring Social Sustainability and Economic Practices: Multi-Journal Compendium. Sustainability 12, pp. 1-7, DOI: $10.3390 /$ su12051718.

DoŁĘGA, W. 2019. Selected aspects of national economy energy efficiency. Polityka Energetyczna - Energy Policy Journal 22(3), pp. 19-32, DOI: 10.33223/epj/111987.

GagnidZE, I. 2018. The Role of International Educational and Science Programs for Sustainable Development (Systemic Approach). Kybernetes 47(2), pp. 409-424, DOI: 10.1108/K-03-2017-01.

GETI 2021. The Global Energy Talent Index Report 2021. Global Energy Talent Index (GETI). [Online] https://www.getireport.com/reports/2021/ [Accessed: 2021-08-19].

GWNET 2019. Women for Sustainable Energy: Strategies to Foster Women's Talent for Transformational Change. Global Women's Network for the Energy Transition (GWNET), 100 pp. [Online] https://www. globalwomennet.org/wp-content/uploads/2020/02/Gwnet-study.pdf [Accessed: 2021-08-19].

IRENA 2019. Renewable Energy: A Gender Perspective. International Renewable Energy Agency (IRENA), 92 pp. [Online] https://www.irena.org/-/media/Files/IRENA/Agency/Publication/2019/Jan/IRENA_Gender_perspective_2019.pdf [Accessed: 2021-08-19].

Lowndes, V. 2010. The Institutional Approach. Edit. By Marsh, D. and Stoker, G. Theories and Methods in Political Science. Basingstoke: Palgrave, pp. 65.

McKinsey and Company 2020. Women in the Workplace 2020, 63 pp. [Online] https://wiw-report.s3.amazonaws.com/Women_in_the_Workplace_2020.pdf [Accessed: 2021-08-15].

Ossowska, L.J and JANISZEwSKA, D.A. 2020. Toward sustainable energy consumption in the European Union. Polityka Energetyczna - Energy Policy Journal 23(1), pp. 37-48. DOI: 10.33223/ epj/119371.

SSSU 2020. Socio-demographic characteristics of Ukrainian households in 2019 (Sotsial'no-demohrafichni kharakterystyky domohospodarstv Ukrayiny). Statistical collection. State Statistics Service of Ukraine (SSSU). [Online] http://www.ukrstat.gov.ua/druk/publicat/Arhiv_u/17/Arch_cdhd_zb.htm [Accessed: 2021-11-04] (in Ukrainian).

UN 2019. Policy Brief 12 Energy and Gender. Accelerating SDG 7 Achievement SDG 7 Policy Briefs in Support of the High-Level Political Forum 2019. United Nations (UN), 207 pp. [Online] https://sustainabledevelopment.un.org/content/documents/22877UN_FINAL_ONLINE_20190523.pdf [Accessed: 2021-08-12].

UNDP 2019. Human Development Index (HDI). United Nations Development Program (UNDP). [Online] http://hdr.undp.org [Accessed: 2021-07 07].

UNFPA 2019. Business Guidelines - How Large, Medium and Small Businesses Benefit from Equality and Domestic Violence Policies (Kerivni pryntsypy dlya biznesu - Yak velykyy, seredniy ta malyy biznes vyhraye vid polityky rivnosti ta zapobihannya domashn'omu nasyl'stvu). United Nations Population Fund (UNFPA), 58 pp. [Online] https://ukraine.unfpa.org/uk/BADVGuide [Accessed: 2021-08-20] (in Ukrainian).

USAID 2021. Gender aspects of employment in the energy sector of Ukraine (Henderni aspekty zaynyatosti $v$ enerhetychnomu sektori Ukrayiny). Energy Security Project Report. Kyiv: U.S. Agency of Inter- 
national Development (USAID), 80 pp. [Online] http://poruch.com.ua/wp-content/uploads/2021/05/ Gender_energy_report-short-web-1.pdf?fbclid=IwAR2ZR18yHcH-O012m-1sxVgvMn7QUe10hDVU2e50fQ4Y2AohzOzNemamjCY [Accessed: 2021-07-10] (in Ukrainian).

WB 2020a. The World Bank in Gender. The World Bank (WB). [Online] https://www.worldbank.org/en/ topic/gender/overview [Accessed: 2021-08-12].

WB 2020b. Women, Business and the Law 2020: 50 years of women's rights. The World Bank (WB) [Online] https://www.worldbank.org/en/news/infographic/2020/03/03/women-business-and-the-law2020-50-years-of-womens-rights [Accessed: 2021-08-11].

WB 2021. Gender Statistics. The World Bank (WB). [Online] https://databank.worldbank.org/reports. aspx ?source $=283 \&$ series $=$ SG.IND.WORK.EQ [Accessed: $2021-08-12]$.

WEF 2020. Global Gender Gap Report 2020. World Economic Forum (WEF), 371 pp. [Online] http:// www3.weforum.org/docs/WEF_GGGR 2020.pdf [Accessed: 2021-08-14].

WEF 2021. Global Gender Gap Report 2021. World Economic Forum (WEF), 405 pp. [Online] http:// www3.weforum.org/docs/WEF_GGGR_2021.pdf [Accessed: 2021-08-14].

Wodon et al. 2020 - Wodon, Q., Onagoruwa, A., Malé, C., Montenegro, C., Nguyen, H., and de la BRIÈRE, B. 2020. How Large Is the Gender Dividend? Measuring Selected Impacts and Costs of Gender Inequality. The Cost of Gender Inequality Notes Series. Washington, DC: World Bank. [Online] https:// openknowledge.worldbank.org/handle/10986/33396 [Accessed: 2021-08-11].

Olena Shatilova, Tetiana Sobolieva, Oleksandr Vostryakov

\title{
Równość płci w sektorze energetycznym: analiza i wzmocnienie pozycji
}

\section{Streszczenie}

\begin{abstract}
Artykuł poświęcony jest aktualnym zagadnieniom równości płci w energetyce. Jest retrospektywną analizą problemu równości płci na przestrzeni ostatnich 50 lat w różnych krajach i sektorach gospodarki. Ogólna sytuacja w zakresie poprawy równowagi płci zmienia się, ale nierównomiernie, co zwiększa znaczenie zwracania uwagi na czynnik płci w opracowywaniu polityki, zwłaszcza w sektorze energetycznym. Ustalono, że w energetyce pozostają tzw. szklane ściany i szklane sufity dla rozwoju kariery zawodowej kobiet, co prowadzi do segregacji poziomej i pionowej. Zwrócono uwagę na główne bariery dla równowagi płci w sektorze energetycznym. Uwarunkowania instytucjonalne zapewniające równość płci w sektorze energetycznym pozwoliły na pełniejsze spojrzenie na problem segregacji zawodowej ze względu na płeć. Wymieniono i scharakteryzowano szereg problemów instytucjonalnych związanych z równością płci w sektorze energetycznym. Należą do nich: niespójność formalnych norm równości płci z istniejącymi praktykami gospodarczymi; brak uwzględniania problematyki płci w tworzeniu polityki energetycznej bez zwrócenia wystarczającej uwagi na relacje społeczne; tworzenie dodatkowych napięć w przemyśle w celu zapewnienia równości płci; bezrobocie pełnosprawnych kobiet z powodu segregacji na rynku pracy w energetyce. Wykorzystując szereg praktycznych propozycji zapewnienia równości płci na poziomie przemysłowym i przedsiębiorstw, autorki proponują
\end{abstract}


koncepcyjny model instytucjonalnego wsparcia równości płci w sektorze energetycznym. Wdrożenie tych propozycji pomogłoby wyeliminować nierówności płci w sektorze energetycznym i promować zrównoważony rozwój przedsiębiorstw energetycznych.

SŁowa KLUCzowe: różnica między płciami, sektor energetyczny, równowaga płci, równość płci, uwarunkowania instytucjonalne 
